\title{
Genotypic evaluation of antimicrobial resistance in Staphylococcus spp. isolated from bovine clinical mastitis
}

[Avaliação genotípica da resistência antimicrobiana em Staphylococcus spp. isolados de mastite clínica bovina]

\author{
N.R. Benites ${ }^{1}$, A.S. Hora ${ }^{2}$, P.L. Mello ${ }^{3}$, M.A. Laes $^{1}$, P.E. Brandão ${ }^{1}$, \\ P.A. Melville ${ }^{1}$, E. Zuniga ${ }^{1 *}$
}

\author{
${ }^{1}$ Faculdade de Medicina Veterinária e Zootecnia - Universidade de São Paulo - São Paulo, SP \\ ${ }^{2}$ Universidade Federal de Uberlândia - Uberlândia, MG \\ ${ }^{3}$ Universidade de Guarulhos - Guarulhos, SP
}

\begin{abstract}
Bovine clinical mastitis caused by Staphylococcus spp. is a serious and widespread disease in the world of dairy farming. Antimicrobial therapy is of fundamental importance in the prevention and treatment of infectious mastitis, but the indiscriminate use of antimicrobials acts as a determining factor for the spread of the disease. The present study evaluated the resistance profiles of 57 Staphylococcus spp. isolated from bovine clinical mastitis to beta-lactams and gentamicin, relating characteristics of phenotype (in vitro susceptibility tests) and genotype (detection and expression of genes encoding resistance - mecA, $m e c A_{L G A 251}$, blaZ, femA, femB, and aacA-aphD - using PCR and RT-PCR, respectively). One or more genes coding for resistance to different antimicrobials were detected in 50 Staphylococcus spp. isolates. The femA and $f e m B$ genes were the most frequent $(75.4 \%$ for both). The observed expression of the genes was as follows: blaZ (60\%), femA (39.5\%), aacA-aphD (50\%), femB (32.6\%), mecA (8.3\%), and mecA $A_{L G A 25 I}(0 \%)$. Considering the relevance of the genus Staphylococcus to bovine mastitis, this study aimed to elucidate aspects regarding the genotypic and phenotypic profiles of these microorganisms so as to contribute to the development of effective strategies for mastitis control.
\end{abstract}

Keywords: staphylococcal mastitis, antimicrobial resistance genes, gene expression

\section{RESUMO}

A mastite clínica bovina causada por Staphylococcus spp. é uma doença grave e generalizada no mundo da pecuária leiteira. A terapia antimicrobiana é de fundamental importância na prevenção e no tratamento da mastite infecciosa, mas o uso indiscriminado de antimicrobianos atua como fator determinante para a disseminação da doença. O presente estudo avaliou os perfis de resistência de 57 Staphylococcus spp. isolados de mastite clínica bovina em relação ao uso de betalactâmicos e gentamicina, relacionando características do fenótipo (testes de suscetibilidade in vitro) e genótipo (detecção e expressão de genes que codificam resistência - mecA, mec $\mathrm{A}_{\mathrm{LGA} 251}$, blaZ, femA, femB, e aacA-aphD - usando PCR e RT-PCR, respectivamente). Um ou mais genes que codificam resistência a diferentes antimicrobianos foram detectados em 50 Staphylococcus spp. isolados. Os genes femA e femB foram os mais frequentes $(75,4 \%$ para ambos). A expressão observada dos genes foi a seguinte: blaZ (60\%), femA (39,5\%), aacA-aphD (50\%), femB (32,6\%), mecA (8,3\%) e mec $\mathrm{A}_{\mathrm{LGA} 251}(0 \%)$. Considerando-se a relevância do gênero Staphylococcus para a mastite bovina, este estudo teve como objetivo elucidar aspectos referentes aos perfis genotípico e fenotípico desses microrganismos, a fim de contribuir para o desenvolvimento de estratégias eficazes para o controle da mastite.

Palavras-chave: mastite estafilocócica, genes de resistência a antimicrobianos, expressão gênica

Recebido em 26 de março de 2020

Aceito em 16 de outubro de 2020

*Autor para correspondência (corresponding author)

E-mail: eveline.zuniga@usp.br 


\section{INTRODUCTION}

Mastitis is an inflammatory process of the mammary gland that interferes directly in milk production and is extremely important for dairy farming. The bacteria most commonly isolated from infectious mastitis are those of the genus Staphylococcus (Côté-Gravel and Malouin, 2018). The control of mastitis has great importance and should be based on therapeutic and preventive measures. Drug therapy assists the animal's defenses in eliminating the invading agent. In turn, microorganisms often seek to nullify the defense response of the host using the most diverse resistance mechanisms, which have been the targets of extensive studies (Ceniti et al., 2017).

Bacterial resistance is related to the existence of different biochemical mechanisms that act to prevent the action of the drugs. Phenotypic and genotypic diagnostic methods for the evaluation of the Staphylococcus spp. resistance profile have been widely used, especially when considering herds of cattle and the possibility of multiresistant pathogens transfer to other animals and humans (Cuny et al., 2011; García-Alvarez et al. 2011; Boireau et al. 2018).

The indiscriminate use of antimicrobials is a risk factor for infection by strains resistant to several antibiotic classes. The increasing rate of bacterial resistance is associated with an exponential increase in the frequency of multi-resistant strains and treatment failures, resulting in a high percentage of morbidity and mortality of animals (Cohn and Middleton, 2010; Ceniti et al. 2017). Considering that the genus Staphylococcus is of great relevance as a mastitis-causing agent, further studies are required regarding their resistance to antimicrobials, particularly those commonly used for the treatment of bovine clinical mastitis.

The use of phenotypic (in vitro antimicrobial susceptibility) and genotypic (molecular techniques for gene detection and gene expression verification) methods to identify the profile of resistant Staphylococcus may help in the development of strategies to control the spread of resistant strains. The objectives of the present study were the evaluation of characteristics of Staphylococcus spp. isolated from bovine clinical mastitis regarding phenotypic and genotypic resistance to the beta-lactams and aminoglycosides most commonly used for the treatment and prevention of this condition.

\section{MATERIAL AND METHODS}

A total of 57 Staphylococcus spp. strains isolated from bovine milk samples presenting clinical mastitis were evaluated. These isolates were previously obtained from the cultivation of milk samples of cows from different dairy farms in the state of Minas Gerais (Brazil). The project was previously approved by the Ethical Committee in the Use of Animals of the Faculty of Veterinary Medicine and Animal Science, University of São Paulo (CEUA/FMVZ) under protocol number 8515270415. All samples were reactive to the Tamis Test (Radostitis et al. 2000) and were submitted to Polimerase Chain Reaction (PCR) for $r p o b$ gene detection for genus confirmation, with subsequent DNA sequencing of the amplified region for determining the species (Mellmann et al. 2006).

In vitro susceptibility tests were conducted using the diffusion technique described by Bauer et al. (1966). The concentrations and interpretation criteria used were those standardized by the Clinical and Laboratory Standards Institute (Performance..., 2008, 2013). The antimicrobials evaluated were amoxicillin $(10 \mu \mathrm{g})$, ampicillin $(10 \mu \mathrm{g})$, oxacillin $(10 \mu \mathrm{g})$, penicillin (10 I.U.), cephalothin $(30 \mu \mathrm{g})$, and gentamicin $(10 \mu \mathrm{g})$. The isolates that presented resistance in the diffusion tests were submitted to the minimum inhibitory concentration (MIC) evaluation using the M.I.C.Evaluator ${ }^{\text {TM }}$ (M.I.C.E. ${ }^{\text {TM}}$ ) (Thermo Fisher Scientific, Basingstoke, UK) according to the manufacturer's instructions and the criteria used to interpret the results were those described by the Clinical and Laboratory Standards Institute (Performance..., 2008, 2013).

Regarding genotypic analysis, the bacterial resistance to beta-lactams was evaluated by the occurrence and expression of the genes mecA, $m e c_{\mathrm{ALGA} 251}$, blaZ, fem $\mathrm{A}$, and $f e m \mathrm{~B}$, whereas the resistance to gentamicin was evaluated by the occurrence and expression of the $a a c \mathrm{~A}-a p h \mathrm{D}$ gene. The DNA and RNA extraction were performed using Illustra ${ }^{\mathrm{TM}}$ Bacteria Genomic Prep Mini Spin Kit (GE Healthcare $®$ ) and Illustra $^{\mathrm{TM}}$ RNASpin Mini Isolation Kit (GE Healthcare () , respectively, according to the 
manufacturer's instructions. The extracts were stored at $-20^{\circ} \mathrm{C}$ for further PCRs to detect antimicrobial resistance encoding genes. After RNA extraction, the samples were quantified using NanoDrop ${ }^{\mathrm{TM}} 2000$ Spectrophotometers (ThermoFisher Scientific $\AA$ ).

Subsequently, the RNA was subjected to cDNA production using SuperScript ${ }^{\mathrm{TM}}$ III (Invitrogen $®$ ) according to the manufacturer's instructions. For gene detection by PCR and evaluation of gene expression by Reverse transcription-polymerase chain reaction (RT-PCR), a pair of primers was used as the endogenous control 16sRNA - F (GTAGGTGGCAAGCGTTATCC) and 16sRNA - R (CGCACATCAGCGTCAG), 228 bp (Monday and Bohac, 1999). To investigate beta-lactams resistance, five pairs of primers were used: blaZ - F (AAGAGATTTGCCTATGCTTC) and blaZ - R (GCTTGACCACTTTTATCAGC), 517 bp (Sawant et al., 2009); mecA - F (TCACCAGGTTCAAC[Y]CAAAA) and mecA - R (CCTGAATC[W]GCTAATAATATTTC), 356 bp (García-Álvarez et al., 2011); mec $_{\text {ALGA251 }}$ - F (GCTCCTAATGCTAATGCA) and $m e c_{\text {ALGA251 }}$ - R (TAAGCAATAATGACTACC), 304 bp (Cuny et al. 2011); femA- F (AGACAAATAGGAGTAATGAT) and femA R (AAATCTAACACTGAGTGATA), 509 bp, and $f e m \mathrm{~B}-\mathrm{F}$ (TTACAGAGTTAACTGTTACC) and $f e m \mathrm{~B}-\mathrm{R}$ (ATACAAATCCAGCACGCTCT), 651 bp (Kobayashi et al., 1994); for resistance to gentamicin the primer $a a c \mathrm{~A}-a p h \mathrm{D}$ was used $-\mathrm{F}$
(TAATCCAAGAGCAATAAGGGC) and aacA$a p h \mathrm{D}$ - R (GCCACACTATCATAACCACTA), 227 bp (Strommenger et al., 2003).

Standard ATCC strains containing the genes under study were used as positive controls: ATCC 700699 for femA and femB; ATCC 700698 for mec $\mathrm{A}$ and $a a c \mathrm{~A}-a p h \mathrm{D}$; ATCC 35984 for blaZ; ATCC BAA-2312 for $m e c_{\mathrm{ALGA} 251}$. PCRs were performed using the PlatinumTM Taq DNA Polymerase kit (Invitrogen $($ ) ) according to the manufacturer's recommendations. Statistical analysis was carried out using the the software GraphPad Instat (Statistical Analysis Systems for Personal Computers 1990-1993) using Fisher's test.

\section{RESULTS}

The antimicrobial susceptibility tests were conducted using 57 Staphylococcus spp. isolates. All samples were sensitive to cephalothin (100\%). High levels of sensitivity were observed in relation to oxacillin and gentamicin, 93\% and $91.2 \%$, respectively. The highest resistance indices $(42.1 \%)$ were found for amoxicillin, ampicillin, and penicillin when compared to the other antimicrobials tested $(\mathrm{P}<0.0001)$. The ranges of minimum inhibitory concentrations (MICs) including the $\mathrm{MIC}_{50}$ and $\mathrm{MIC}_{90}$ for the isolates that showed resistance in the diffusion tests are presented in Table 1.

Table 1. Ranges of minimum inhibitory concentrations (MICs), $\mathrm{MIC}_{50}$ and $\mathrm{MIC}_{90}$ regarding the isolates that presented resistance in the diffusion tests

\begin{tabular}{lccc}
\hline \multicolumn{1}{c}{ Antimicrobial } & MIC $($ Range for most strains $-\mu \mathrm{g} / \mathrm{mL})$ & MIC $_{50}$ & MIC90 \\
\hline Oxacillin $(\mathrm{N}=4)$ & $0.5-2$ & $\leq 0.5$ & $\leq 1$ \\
Penicillin $(\mathrm{N}=24)$ & $0.25-16$ & $\leq 2$ & $\leq 16$ \\
Amoxicillin $(\mathrm{N}=24)$ & $0.5-2$ & $\leq 1$ & $\leq 2$ \\
Ampicillin $(\mathrm{N}=24)$ & $0.5-2$ & $\leq 1$ & $\leq 2$ \\
Gentamicin $(\mathrm{N}=5)$ & $16-128$ & $\leq 64$ & $\leq 128$ \\
\hline
\end{tabular}

In relation to the detection of genes related to bacterial resistance it was observed that one or more genes that were investigated (mecA, $m e c_{\mathrm{ALGA} 251}$, blaZ, fem $\mathrm{A}, f e m \mathrm{~B}$, and $\operatorname{aac\mathrm {A}-aph\mathrm {D})}$ were detected in $50(87.7 \%)$ Staphylococcus spp. isolates. Table 2 presents the occurrence of the genes associated with antimicrobial resistance as well as the occurrence of the expression of these genes according to the Staphylococcus species. The fem $\mathrm{A}$ and $f e m \mathrm{~B}$ genes were the most frequent $(\mathrm{N}=43,75.4 \%) \quad(P<0.0001)$. Different genes combinations were detected: fem $\mathrm{A} /$ fem $\mathrm{B}(\mathrm{N}=28$; $49.1 \%)$, fem $\mathrm{A} /$ fem $\mathrm{B} /$ aac $\mathrm{A}-a p h \mathrm{D}(\mathrm{N}=6 ; 10.5 \%)$, and $f e m \mathrm{~A} / f e m \mathrm{~B} / m e c \mathrm{~A} / a a c \mathrm{~A}-a p h \mathrm{D}(\mathrm{N}=5 ; 8.8 \%)$ among others that occurred to a lesser extent. For $S$. aureus, the most frequent gene combination was femA/femB $(65.9 \%)(P<0.007)$.

Regarding the presence of the femA gene in Staphyococcus species, it was possible to verify its occurrence in species other than $S$. aureus (two samples of $S$. agnetis and one of S. xylosus). The 
femA gene was detected in $97.6 \%$ of $S$. aureus. The expression of the genes $f e m \mathrm{~A}$ and $f e m \mathrm{~B}$ occurred only in S. aureus $(42.5 \%$ for femA and $35 \%$ for $f e m \mathrm{~B}$ ) (Table 2). Regarding the mec $\mathrm{A}$ gene, none of the isolates of $S$. aureus or the other coagulase-positive Staphylococcus isolates showed expression of this gene, whereas a sample of $S$. haemolyticus was positive. The mec $\mathrm{A}_{\mathrm{LGA} 251}$ gene was detected in an $S$. equorum isolate but expression of the gene was not observed. The blaZ gene was detected in five samples, and the expression of the gene was verified in one $S$. aureus and two $S$. haemolyticus isolates. Regarding the aacA-aph $\mathrm{D}$ gene, its expression was observed in $100 \%$ of coagulase negative Staphylococcus and in $55.6 \%$ of $S$. aureus (Table 2).

Table 2. Classification of 57 Staphylococcus strains (S. aureus, S. agnetis, S. xylosus, S. epidermidis, S. equorum, $S$. haemolyticus) isolated from bovine clinical mastitis according to the presence and expression of genes coding for resistance to different antimicrobials

\begin{tabular}{|c|c|c|c|c|c|c|c|c|c|c|c|c|c|c|c|c|c|c|c|c|c|c|c|c|c|c|}
\hline \multirow[b]{2}{*}{ 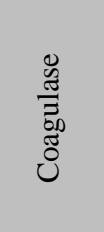 } & \multirow[b]{2}{*}{ 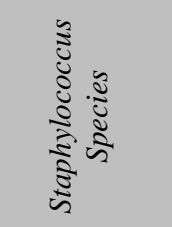 } & \multirow[b]{2}{*}{$\mathrm{N}$} & \multicolumn{4}{|c|}{ fem $A$} & \multicolumn{4}{|c|}{ fem $\mathrm{B}$} & \multicolumn{4}{|c|}{$m e c \mathrm{~A}$} & \multicolumn{4}{|c|}{ aacA-aph $D$} & \multicolumn{4}{|c|}{$\operatorname{mec}_{L G A 251}$} & \multicolumn{4}{|c|}{ blaZ } \\
\hline & & & & 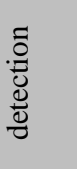 & & 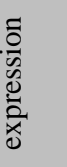 & & 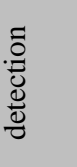 & & 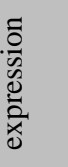 & & 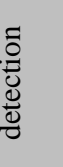 & & 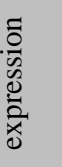 & & $\begin{array}{l}.00 \\
\stackrel{0}{0} \\
\frac{d}{0}\end{array}$ & & 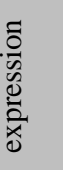 & & 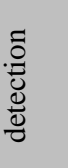 & & 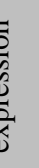 & & $\begin{array}{l}\frac{0}{0} \\
\frac{0}{0} \\
\frac{0}{0}\end{array}$ & & 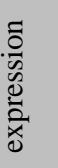 \\
\hline \multirow{3}{*}{ Positive } & & & $\mathrm{N}$ & $\%$ & $\mathrm{~N}$ & $\%$ & $\mathrm{~N}$ & $\%$ & $\mathrm{~N}$ & $\%$ & $\mathrm{~N}$ & $\%$ & $\mathrm{~N}$ & $\%$ & $\mathrm{~N}$ & $\%$ & $\mathrm{~N}$ & $\%$ & $\mathrm{~N}$ & $\%$ & $\mathrm{~N}$ & $\%$ & $\mathrm{~N}$ & $\%$ & $\mathrm{~N}$ & $\%$ \\
\hline & S. aureus & 41 & 40 & 97.6 & 17 & 42.5 & 40 & 97.6 & 14 & 35 & 7 & 17.1 & 0 & 0 & 9 & 22.0 & 5 & 55.6 & 0 & 0.0 & 0 & 0 & 1 & 2.4 & 1 & 100 \\
\hline & S. hyicus & 6 & 0 & 0.0 & 0 & 0 & 0 & 0.0 & 0 & 0 & 3 & 50.0 & 0 & 0 & 2 & 33.3 & 0 & 0 & 0 & 0.0 & 0 & 0 & 1 & 16.7 & 0 & 0 \\
\hline \multirow[t]{2}{*}{$\begin{array}{l}\text { other } \\
\text { CPS }\end{array}$} & S. agnetis & 2 & 2 & 100.0 & 0 & 0 & 2 & 100.0 & 0 & 0 & 1 & 50.0 & 0 & 0 & 2 & 100.0 & 0 & 0 & 0 & 0.0 & 0 & 0 & 0 & 0.0 & 0 & 0 \\
\hline & CPS total & 8 & 2 & 25.0 & 0 & 0 & 2 & 25.0 & 0 & 0 & 4 & 50.0 & 0 & 0 & 4 & 50.0 & 0 & 0 & 0 & 0.0 & 0 & 0 & 1 & 12.5 & 0 & 0 \\
\hline \multirow{6}{*}{$\begin{array}{l}\text { Negative } \\
\text { CNS }\end{array}$} & S. xylosus & 1 & 1 & 100.0 & 0 & 0 & 1 & 100.0 & 0 & 0 & 0 & 0.0 & 0 & 0 & 0 & 0.0 & 0 & 0 & 0 & 0.0 & 0 & 0 & 0 & 0.0 & 0 & 0 \\
\hline & S.epidermidis & 2 & 0 & 0.0 & 0 & 0 & 0 & 0.0 & 0 & 0 & 0 & 0.0 & 0 & 0 & 0 & 0.0 & 0 & 0 & 0 & 0.0 & 0 & 0 & 0 & 0.0 & 0 & 0 \\
\hline & S. equorum & 2 & 0 & 0.0 & 0 & 0 & 0 & 0.0 & 0 & 0 & 0 & 0.0 & 0 & 0 & 0 & 0.0 & 0 & 0 & 1 & 50.0 & 0 & 0 & 1 & 50.0 & 0 & 0 \\
\hline & S.haemolyticus & 3 & 0 & 0.0 & 0 & 0 & 0 & 0.0 & 0 & 0 & 1 & 33.3 & 1 & 100 & 3 & 100.0 & 3 & 100 & 0 & 0.0 & 0 & 0 & 2 & 66.7 & 2 & 100 \\
\hline & CNS total & 8 & 1 & 12.5 & 0 & 0 & 1 & 12.5 & 0 & 0 & 1 & 12.5 & 1 & 100 & 3 & 37.5 & 3 & 100 & 1 & 12.5 & 0 & 0 & 3 & 37.5 & 2 & 66.7 \\
\hline & Total & 57 & 43 & 75.4 & 17 & 39.5 & 43 & 75.4 & 14 & 32.6 & 12 & 21.1 & 1 & 8.33 & 16 & 28.1 & 8 & 50 & 1 & 1.8 & 0 & 0 & 5 & 8.8 & 3 & 60 \\
\hline
\end{tabular}

Table 3 shows the results regarding the detection and expression of genes associated with antimicrobial resistance, and the association of these results with those of resistance obtained in the phenotypic tests. Regarding the mecA gene, the only sample positive for expression also presented phenotypic resistance to ampicillin, amoxicillin, oxacillin, and penicillin. It should be noted that of the 12 samples in which the gene was detected, in $11(91.7 \%)$ of these there was no gene expression (Table 3). Regarding the blaZ gene, three isolates showed expression and phenotypic resistance to the beta-lactams which were tested, except for oxacillin.
When considering the fem $\mathrm{A}$ and $f e m \mathrm{~B}$ genes, it was verified that the expression of these genes was not associated with the occurrence of resistance in phenotypic tests with amoxicillin, ampicillin, and penicillin $(P<0.05)$. The same was observed for the $a a c \mathrm{~A}-a p h \mathrm{D}$ gene and the resistance to gentamicin (Table 3). Concerning the mecA gene the concordance between expression of the genes and phenotypic resistance was very good for oxacillin and in the case of the blaZ gene, very good agreement was observed for ampicillin, amoxicillin, and penicillin. 
Table 3. Classification of 57 Staphylococcus strains (S. aureus, S. agnetis, S. xylosus, S. epidermidis, S. equorum, $S$. haemolyticus) isolated from bovine clinical mastitis, according to the detection and expression of genes associated with antimicrobial resistance, and to the occurrence of phenotypic resistance to amoxicillin, ampicillin, oxacillin, penicillin, and gentamicin

\begin{tabular}{|c|c|c|c|c|c|c|c|c|c|c|c|c|c|c|}
\hline \multirow[t]{2}{*}{ gene } & \multirow{2}{*}{$\begin{array}{c}\text { Gene } \\
\text { Detection }\end{array}$} & \multirow[t]{2}{*}{$\mathrm{N}$} & \multirow[t]{2}{*}{$\%$} & \multirow{2}{*}{$\begin{array}{c}\text { Gene } \\
\text { Expression }\end{array}$} & \multirow[t]{2}{*}{$\mathrm{N}$} & \multirow[t]{2}{*}{$\%$} & \multicolumn{2}{|c|}{$\begin{array}{l}\text { Ampicillin/ } \\
\text { Amoxicillin }\end{array}$} & \multicolumn{2}{|c|}{ Oxacillin } & \multicolumn{2}{|c|}{ Penicillin } & \multicolumn{2}{|c|}{ Gentamicin } \\
\hline & & & & & & & $\mathrm{N}$ & $\%$ & $\mathrm{~N}$ & $\%$ & $\mathrm{~N}$ & $\%$ & $\mathrm{~N}$ & $\%$ \\
\hline \multirow{3}{*}{ fem $\mathrm{A}$} & \multirow{2}{*}{ present } & \multirow{2}{*}{43} & \multirow{2}{*}{75.4} & present & 17 & 39.5 & 6 & 35.3 & 0 & 0.0 & 6 & 35.3 & 3 & 17.6 \\
\hline & & & & absent & 26 & 60.5 & 11 & 42.3 & 1 & 3.8 & 11 & 42.3 & 0 & 0.0 \\
\hline & absent & 14 & 24.6 & -- & -- & -- & 7 & 50.0 & 3 & 21.4 & 7 & 50.0 & 2 & 14.3 \\
\hline \multirow{3}{*}{ fem $\mathrm{B}$} & \multirow{2}{*}{ present } & \multirow{2}{*}{43} & \multirow{2}{*}{75.4} & present & 14 & 32.6 & 4 & 28.6 & 0 & 0.0 & 4 & 28.6 & 3 & 21.4 \\
\hline & & & & absent & 29 & 67.4 & 13 & 44.8 & 1 & 3.4 & 13 & 44.8 & 0 & 0.0 \\
\hline & absent & 14 & 24.6 & -- & -- & -- & 7 & 50.0 & 3 & 21.4 & 7 & 50.0 & 2 & 14.3 \\
\hline \multirow{3}{*}{ mecA } & \multirow{2}{*}{ present } & \multirow{2}{*}{12} & \multirow{2}{*}{21.1} & present & 1 & 8.3 & 1 & 100.0 & 1 & 100.0 & 1 & 100.0 & 1 & 100.0 \\
\hline & & & & absent & 11 & 91.7 & 3 & 27.3 & 0 & 0.0 & 3 & 27.3 & 0 & 0.0 \\
\hline & absent & 45 & 78.9 & -- & -- & -- & 20 & 44.4 & 3 & 6.7 & 20 & 44.4 & 4 & 8.9 \\
\hline \multirow{3}{*}{$m e c \mathrm{~A}_{\mathrm{LGA} 251}$} & \multirow{2}{*}{ present } & \multirow{2}{*}{1} & \multirow{2}{*}{1.8} & present & 0 & 0.0 & 0 & 0.0 & 0 & 0.0 & 0 & 0.0 & 0 & 0.0 \\
\hline & & & & absent & 1 & 100.0 & 0 & 0.0 & 0 & 0.0 & 0 & 0.0 & 0 & 0.0 \\
\hline & absent & 56 & 98.2 & -- & -- & -- & 24 & 42.9 & 4 & 7.1 & 24 & 42.9 & 5 & 8.9 \\
\hline \multirow{3}{*}{ blaZ } & \multirow{2}{*}{ present } & \multirow{2}{*}{5} & \multirow{2}{*}{8.8} & present & 3 & 60.0 & 3 & 100.0 & 1 & 33.3 & 3 & 100.0 & 1 & 33.3 \\
\hline & & & & absent & 2 & 40.0 & 0 & 0.0 & 0 & 0.0 & 0 & 0.0 & 0 & 0.0 \\
\hline & absent & 52 & 91.2 & -- & -- & -- & 21 & 40.4 & 3 & 5.8 & 21 & 40.4 & 4 & 7.7 \\
\hline \multirow{3}{*}{$a a c \mathrm{~A}-a p h \mathrm{D}$} & present & 16 & 281 & present & 8 & 50.0 & 3 & 37.5 & 1 & 12.5 & 3 & 37.5 & 5 & 62.5 \\
\hline & present & 10 & 28.1 & absent & 8 & 50.0 & 0 & 0.0 & 0 & 0.0 & 0 & 0.0 & 0 & 0.0 \\
\hline & absent & 41 & 71.9 & -- & -- & -- & 21 & 51.2 & 3 & 7.3 & 21 & 51.2 & 0 & 0.0 \\
\hline
\end{tabular}

\section{DISCUSSION}

Antimicrobial therapy is a very important tool in mastitis control and treatment, although the increasing resistance to antimicrobials presented by microorganisms represents an important cause of therapeutic failure (Boireau et al. 2018). Different types of antimicrobials are used to treat and control bovine mastitis for lactating or drying cows. The use of beta-lactams and aminoglycosides as important antimicrobials used in bovine mastitis therapies has been reported (Srednik et al. 2017a; Martins et al. 2016).

Krewer et al. (2015) emphasized that intramammary treatment is not always effective, and resistance to the beta-lactams group may occur as they are routinely used to treat intramammary infections. Other researchers also report the occurrence of penicillin resistance (Rabello et al. 2005; Schmidt et al., 2015). In the present study, the resistance rate found for penicillin was $42.1 \%$, and the same was found for amoxicillin and ampicillin. Costa et al. (2013) conducted a study with 35 dairy herds located in Minas Gerais, Brazil, that had cases of mastitis caused by Staphylococcus aureus and found higher resistance rates of $80.9 \%$ and $80.5 \%$ to ampicillin and penicillin, respectively. Sensitivity to oxacillin was also observed in over $90 \%$ of samples. Mistry et al. (2016) obtained $100 \%$ of $S$. aureus isolated from bovine intramammary infections sensitive to oxacillin.

The presence of genes associated with antimicrobial resistance was investigated in all Staphylococcus strains. The most frequently detected genes were fem $\mathrm{A}(75.4 \%)$ and $f e m \mathrm{~B}$ (75.4\%), and according to Hussain et al. (2013) these are genes associated with the expression of methicillin resistance (MRSA - methicillin resistant Staphylococcus aureus) and are specific genes related to $S$. aureus. In the present study, it was found that $97.6 \%$ (40/41) of S. aureus isolates presented the femA gene, which was also found in two samples of $S$. agnetis and one of S. xylosus. Therefore, the fem $\mathrm{A}$ gene can also be found in Staphylococcus species other than coagulase positive Staphylococcus (CPS). Lange et al. (2011) evaluated $100 \mathrm{~S}$. aureus isolates from milk of cows with clinical or subclinical mastitis and detected fem $\mathrm{A}$ in 83 of them, and the gene was not detected in S. chromogenes $(\mathrm{N}=13)$ and S. hyicus $(\mathrm{N}=4)$.

The presence of the $f e m \mathrm{~B}$ gene was detected in $75.4 \%(43 / 57)$ of the isolates. When the presence 
of the gene was evaluated in S. aureus, $97.6 \%$ (40/41) isolates were detected as positives, similar to the detection of the $f e m \mathrm{~B}$ gene in $97 \%$ $(192 / 198)$ of $S$. aureus samples by Kobayashi et al. (1994). The presence of the gene was also observed in other species, such as S. agnetis and S. xylosus, contrary to the results of Kobayashi et al. (1994) who did not verify the presence of the gene in SCN. López-Vazques et al. (2015) obtained different results than those verified by the present study, as they isolated $28.1 \%$ $(\mathrm{N}=85 / 302)$ strains of $S$. aureus positive for the fem $\mathrm{B}$ gene.

The most frequent gene combination that was detected was femA/femB. The presence or absence of these genes was not a determinant for the occurrence of phenotypic resistance to the beta-lactams which were evaluated, indicating that other factors besides the presence of the genes probably influence the occurrence of resistance. Until the mid-1990s, MRSA exhibited phenotypic multidrug resistance and over time, the presence of the mecA gene became an important marker for indicating MRSA infections in view of their increased occurrence (Cuny et al. 2011). In the present study, the presence of the mecA gene was detected in 12 samples (21.1\%): seven S. aureus, one $S$. agnetis, one $S$. haemolyticus, and three $S$. hyicus.

Regarding S. aureus, the frequency was $17.1 \%$ (N =7/41). The presence of the mecA gene was also detected in CNS (one S. haemolyticus), similar to the results obtained by other researchers such as Soares et al. (2012) who detected the mecA gene in $13.8 \%(4 / 29)$ of oxacillin resistant CNS (Staphylococcus xylosus) isolated from bovine mastites and Frey et al. (2013) who isolated CNS $(\mathrm{n}=370)$ from milk obtained from cows with clinical $(\mathrm{n}=115)$ and subclinical $(\mathrm{n}=255)$ mastitis and detected 19 strains containing mecA gene - S. epidermidis, S. fleurettii, S. haemolyticus and S. xylosus.

Fessler et al. (2010a) investigated the occurrence of resistance to oxacillin and the presence of the $m e c \mathrm{~A}$ gene in $121 \mathrm{CNS}$ isolates from bovine mastitis on properties in Germany; 16 of these isolates showed resistance to oxacillin and the gene was detected in 15 of them. Frey et al. (2013) identified the mecA gene in $9.7 \%(\mathrm{n}=19)$ of the oxacillin-resistant CNS isolates $(\mathrm{n}=196)$ and the gene was not detected in the other 177 oxacillin- resistant isolates (90.3\%). Soares et al. (2012) isolated $100 \mathrm{CNS}$ strains from milk from dairy cows in six different towns comprising an important milk production region of the State of Rio de Janeiro, Brazil; four isolates were positive to mecA gene (4\%), all S. xylosus and the gene was detected in $13.8 \%(4 / 29)$ of the oxacillin resistant CNS.

In the present study, considering the 12 Staphylococcus isolates in which mecA was detected, it was observed that one $(8.3 \%)$ was oxacillin-resistant and $11(91.7 \%)$ oxacillinsensitive. Regarding the $S$. aureus samples, all seven samples in which the gene was detected were oxacillin sensitive. It was found that in the presence of the gene there was a higher frequency of phenotypic resistance than in its absence $(P<0.0001)$. In turn, Silva et al. (2014) isolated twenty-six methicillin-resistant CNS ( $S$. epidermidis, S. chromogenes, $S$. warneri, $S$. hyicus and $S$. simulans) from milk of mastitic cows in Brazil, and all isolates carried mec $\mathrm{A}$ and were oxacillin resistant.

The mec $\mathrm{A}_{\mathrm{LGA} 251}$ (mec $\mathrm{C}$ ), a mec $\mathrm{A}$ homolog gene, was found in a sample of $S$. equorum which was sensitive for all beta-lactams which were evaluated and was negative for the evaluation of gene expression. Srednik et al. (2017b) reported for the first time, one CNS (Staphylococcus saprophyticus) isolated from bovine mastitis in South America that was resistant to beta-lactams and positive for the mec $\mathrm{C}$ gene. Dhaouadi et al. (2020) also reported the occurrence of the mecC gene in MR-CNS (three Staphylococcus sciuri isolates) from cows' milk and manure in Tunisia and Africa. Unnerstad et al. (2013) investigated $730 \mathrm{~S}$. aureus samples isolated from bovine mastitis and confirmed MRSA, having detected the mec $\mathrm{A}_{\mathrm{LGA} 251}$ gene in $4(0.5 \%)$ of these.

The bla $\mathrm{Z}$ gene, that can be found on both the chromosome and plasmids, was detected at reduced frequency when the totality of the isolates was considered $(8.8 \%)$ as well as in the $S$. aureus samples (2.4\%). In turn Ruegg et al. (2015) evaluated $35 \mathrm{~S}$. aureus isolates and $51 \mathrm{CNS}$ isolates from bovine mastitis samples and detected the presence of the blaZ gene in 46 $(53.5 \%)$ isolates. Regarding the $41 \mathrm{~S}$. aureus isolates, the concomitant presence of the mecA, fem $\mathrm{A}$, and fem $\mathrm{B}$ genes - important for a safer identification of MRSA (Kobayashi et al. 1994) - 
had a low frequency of occurrence $(7.3 \%)$. The most frequent gene combination was $f e m \mathrm{~A} / f e m \mathrm{~B}$ for both Staphylococcus spp. (49.1\%) and $S$. aureus (65.9\%).

The presence of the $a a c \mathrm{~A}-a p h \mathrm{D}$ gene, which codes for enzymes that act on aminoglycosides, was detected in $28.1 \%(16 / 57)$ of the Staphylococcus spp. isolates and 22\% (9/41) of the $S$. aureus isolates. The aacA-aphD gene was detected in $62.5 \%(5 / 16)$ of the isolates phenotypically resistant to gentamicin. Fessler et al. (2010b) evaluated 27 MRSA isolates (25 isolates from clinical bovine mastitis and two isolates from dairy farm workers) and $100 \%$ of the samples that were phenotypically resistant to gentamicin $(\mathrm{N}=6)$ also presented the $a a c \mathrm{~A}-a p h \mathrm{D}$ gene.

One of the objectives of the present study, considering the lack of information on the subject, was to relate data on the detection and expression of genes encoding resistance to antimicrobials most commonly used in clinical bovine practice in Staphylococcus isolated from cases of clinical bovine mastitis. The occurrence of expression was observed for all genes that were evaluated except for mec $\mathrm{A}_{\mathrm{LGA} 251}$; blaZ (60\%), femA (39.5\%), aac $\mathrm{A}-a p h \mathrm{D}(50 \%), f e m \mathrm{~B}(32.6 \%)$, and mec $\mathrm{A}$ $(8.3 \%)$. It was observed that the presence of the gene was not necessarily associated with its expression when all the cases in which they were detected were considered.

It was also verified that, for the $f e m \mathrm{~A}$ and $f e m \mathrm{~B}$ genes, the expression of these genes was observed only in S. aureus and that none of the $7 \mathrm{~S}$. aureus isolates in which the mecA gene was detected showed gene expression. Only one of eight CNS samples presented the mecA gene positive for

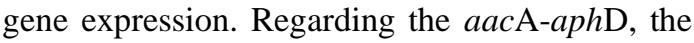
expression of the gene was observed in all CNSs $(\mathrm{N}=3)$ in which the gene was detected, and in $55.6 \%$ of the $S$. aureus samples positive for the occurrence of the gene. The evaluation of the variables genes expression versus phenotypic resistance showed very good concordance regarding blaZ gene versus ampicillin, amoxicillin, and penicillin, as well as mecA versus oxacillin. From this perspective, it is possible that the blaZ gene may have a more relevant participation in the occurrence of phenotypic resistance to ampicillin, amoxicillin, and penicillin as well as mec A against oxacillin.

\section{CONCLUSIONS}

The results show that the presence of a specific gene is not necessarily associated with its genotypic and/or phenotypic expression, as well as the occurrence of gene expression may not be necessarily associated with its phenotypic expression. The results of the present study reinforce the importance of conducting further research in order to clarify aspects involved in the occurrence of gene expression associated with antimicrobial resistance, whether genetic or not. Research on this subject will shed more light on the behavior of microorganisms towards antimicrobials, and consequently, should help in the development of new strategies for the control and treatment of mastitis in dairy herds around the world.

\section{ACKNOWLEDMENTS}

This work was supported by FAPESP (The São Paulo State Foundation to Support Research), Grant no.2015/14209-4.

\section{REFERENCES}

BAUER, A.W.; KIRBY, W.M.; SHERRIS, J.C.; TURCK, M. Antibiotic susceptibility testing by a standardized single disk method. Am. J. Clin. Pathol., v.45, p.493-496, 1966.

BOIREAU, C.; CAZEAU, G.; JARRIGE, N. et al. Antimicrobial resistance in bacteria isolated from mastitis in dairy cattle in France, 2006-2016. J. Dairy Sci., v.101, p.9451-9462, 2018.

CENITI, C.; BRITTI, D.; SANTORO, A.M.L. et al. Phenotypic antimicrobial resistance profile of isolates causing clinical mastitis in dairy animals. Ital. J. Food Saf., v.6, p.6612, 2017.

COHN, L.A.; MIDDLETON, J.R. A veterinary perspective on methicillin-resistant staphylococci. J. Vet. Emerg. Crit. Care, v.20, p.31-45, 2010.

COSTA, G.M.; BARROS, R.A.; COSTA CUSTÓDIO, D.A. et al. Resistência a antimicrobianos em Staphylococcus aureus isolados de mastite em bovinos leiteiros de Minas Gerais, Brasil. Arq. Bras. Med. Vet. Zootec., v.80, p.297-302, 2013. 
CÔTÉ-GRAVEL, J.; MALOUIN, F. Symposium review: features of Staphylococcus aureus mastitis pathogenesis that guide vaccine development strategies. J. Dairy Sci., v.102, p.4727-4740, 2018.

CUNY, C.; LAYER, F.; STROMMENGER, B.; WITTE, W. Rare occurrence of methicillinresistant Staphylococcus aureus cc130 with a novel mecA homologue in humans in Germany. PLOS One v.6, p.1-5, 2011.

DHAOUADI, S.; SOUFI L.; CAMPANILE F. et al. Prevalence of meticillin-resistant and susceptible coagulase-negative staphylococci with the first detection of the mec $\mathrm{C}$ gene among cows, humans and manure in Tunisia. Int. J. Antimicrobiol. Agents, v.55, p.105826, 2020.

FESSLER, A.; BILLERBECK, C.; KADLEC, K.; SCHWARZ, S. Identification and characterization of methicillin-resistant coagulase-negative staphylococci from bovine mastitis. $J$. Antimicrobiol. Chemother., v.65, p.1576-1582, 2010a.

FESSLER, A.; SCOTT, C.; KADLEC, K. et al. Characterization of methicillin-resistant Staphylococcus aureus ST398 from cases of bovine mastitis. J. Antimicrobiol. Chemother., v.65, p.619-625, 2010b.

FREY, Y.; RODRIGUEZ, J.P.; THOMANN, A.; SCHWENDENER, S.; PERRETEN, V. Genetic characterization of antimicrobial resistance in coagulase-negative staphylococci from bovine mastitis milk. J. Dairy Sci., v.96, p.2247-225, 2013.

GARCÍA-ALVAREZ，L.; HOLDEN，M.T.G.; LINDSAY, H.E.K. et al. Meticillin-resistant Staphylococcus aureus with a novel mecA homologue in human and bovine population in the UK and Denmark: a descriptive study. Lancet Infect. Dis., v.11, p.595-603, 2011.

HUSSAIN, S.F.; KHATOON, A.; SHAHID, S.M.; ISMAIL, M.; AZHAR, A. Discriminative multiplex (hexaplex) PCRstrategy for the detection of methicillin resistance and virulence factors in Staphylococcus aureus. Afr. J. Microbiol. Res., v.7, p.196-201, 2013.

KOBAYASHI, N.; WU, H.; KOJIMA, K. et al. Detection $m e c A, f e m A$ and $f e m B$ genes in clinical strains of staphylococci using polymerase chain reaction. Epidemiol. Infec., v.113, p.259-266, 1994.
KREWER, C.C.; AMANSO, E.S.; GOUVEIA, G.V. et al. Resistance to antimicrobials and biofilm formation in Staphylococcus spp. isolated from bovine mastitis in the Northeast of Brazil. Trop. Anim. Health Prod., v.47, p.511-518, 2015.

LANGE, C.C.; BRITO, M.A.V.P.; BRITO, J.R.F. et al. Uso de PCR e sequenciamento do rDNA 16S para identificação de bactérias do gênero Staphylococcus isoladas de mastite bovina. Pesqui. Vet. Bras., v.31, p.36-40, 2011.

LÓPEZ-VAZQUEZ, M.; MASTÍNEZCASTANEDA, J.S.; TALAVERA-ROJAS, M. et $a l$. Detection of mecA, mecI and mecRl genes in methicillin-resistant Staphylococcus aureus strains of bovine origin isolated from Family Dairy Farms, Mexico. Arch. Med. Vet., v.47, p.245-249, 2015.

MARTINS, T.; ROSA, A.F.; CASTELANI, L. et al. Intramammary treatment with gentamicin in lactating cows with clinical and subclinical mastitis. Pesqui. Vet. Bras., v.36, p.283-289, 2016.

MELLMANN, A.; BECKER, K.; VON EIFF, C. et al. Sequencing and Staphylococci identification. Emerg. Infect. Dis., v.12, p.333336, 2006.

MISTRY, H.; SHARMA, P.; MAHATO, S. et al. Prevalence and characterization of oxacillin susceptible mecA-positive clinical isolates of Staphylococcus aureus causing bovine mastitis in India. PLoS One, v.11, p.e0162256, 2016.

MONDAY, S.R.; BOHAC, G.A. Use of multiplex PCR to detect classical and newly described pyrogenic toxin genes in Staphylococcal isolates. J. Clin. Microbiol., v.37, p.3411-3414, 1999.

PERFORMANCE standards for antimicrobial disk and dilution susceptibility tests for bacteria isolated from animal: approved standard M31-A3. 3.ed. Wayne: CLSI, 2008. v.28.

PERFORMANCE standards for antimicrobial disk and dilution susceptibility tests for bacteria isolated from animals: second informational supplement VET01-S2. Wayne: CLSI, 2013. v.33.

RADOSTITIS O. M.; GAY, C. C.; BLOOD, D. C. Veterinary medicine: a textbook of the disease of cattle, sheep, pigs, goats and horses. 9th Ed, (Saunders, Philadelphia), 2000. 
RABELLO, R.F.; SOUZA, C.R.; DUARTE, R.S. et al. Characterization of Staphylococcus aureus isolates recovered from bovine mastitis in Rio de Janeiro, Brazil. J. Dairy Sci., v.88, p.3211-3219, 2005.

RUEGG, P.L.; OLIVEIRA， L.; JIN， W.; OKWUMABUA, O. Phenotypic antimicrobial susceptibility and occurrence of selected resistance genes in gram-positive mastitis pathogens isolated from Wisconsin dairy cows. $J$. Dairy Sci., v.98, p.4521-4534, 2015.

SAWANT, A.A.; GILLESPIE, B.E.; OLIVER, S.P. Antimicrobial susceptibility of coagulasenegative Staphylococcus species isolated from bovine milk. Vet. Microbiol., v.134, p.73-81, 2009.

SCHMIDT, T.; KOCK, M.M.; EHLERS, M.M. Diversity and antimicrobial susceptibility profiling of staphylococci isolated from bovine mastitis cases and close human contacts J. Dairy Sci., v.98, p.6256-6269, 2015.

SILVA, N.C.C.; GUIMARÃES, F.F.; MANZI, M.P. et al. Characterization of methicillinresistant coagulase-negative staphylococci in milk from cows with mastitis in Brazil. Antonie Van Leeuwenhoek, v.106, p.227-233, 2014.
SOARES, L.C.; PEREIRA, I.A.; PRIBUL, B.R. et al. Antimicrobial resistance and detection of $m e c \mathrm{~A}$ and blaZ genes in coagulase-negative Staphylococcus isolated from bovine mastitis. Pesqui. Vet. Bras., v.32, 692-696, 2012.

SREDNIK, M.E.; ARCHAMBAULT, M.; JACQUES, M.; GENTILINI, E. R.Detection of a mecC-positive Staphylococcus saprophyticus from bovine mastitis in Argentina. J. Glob. Antimicrob. Resist., v.10, p.261-263, 2017b.

SREDNIK, M.E.; TREMBLAY, Y.D.N.M.; LABRIE, J. et al. Biofilm formation and antimicrobial resistance genes of coagulasenegative staphylococci isolated from cows with mastitis in Argentina. FEMS Microbiol. Lett., v.364, n.8, 2017a.

STROMMENGER, B.; KETTLITZ, C.; WERNER, G.; WITTE, W. Multiplex PCR assay for simultaneous detection of nine clinically relevant antibiotic resistance in Staphylococcus aureus. J. Clin. Microbiol., v.41, p.4089-4094, 2003.

UNNERSTAD, H.E.; BENGTSSON, B.; HORN AF RANTZIEN M.; BORJESSON, S. Methicillin-resistant Staphylococcus aureus containing mecC in Swedish dairy cows. Acta Vet. Scand., v.55, p.6, 2013. 